\title{
The Performance of Four Different Mineral Liners on the Transportation of Chlorinated Phenolic Compounds to Groundwater in Landfills
}

\author{
Elanur Adar and Mehmet Sinan Bilgili \\ Department of Environmental Engineering, Faculty of Civil Engineering, Yildiz Technical University, \\ Davutpasa, Esenler, 34220 Istanbul, Turkey \\ Correspondence should be addressed to Elanur Adar; aelanur@yildiz.edu.tr
}

Received 23 July 2015; Revised 9 November 2015; Accepted 15 November 2015

Academic Editor: Cezary Sławiński

Copyright ( 2015 E. Adar and M. S. Bilgili. This is an open access article distributed under the Creative Commons Attribution License, which permits unrestricted use, distribution, and reproduction in any medium, provided the original work is properly cited.

\begin{abstract}
The aim of this study was to investigate the efficiency of four different mineral liners (clay, bentonite, kaoline, and zeolite) which could be utilized to prevent the transport of phenolic compounds to groundwater through alternative liner systems. Four laboratoryscale HDPE reactors with $80 \mathrm{~cm}$ height and $40 \mathrm{~cm}$ inner diameter were operated for a period of 180 days. Results indicated that the transport of mono- or dichlorophenols is significantly prevented by the liner systems used, while the transport of highly chlorinated phenolic compounds cannot be prevented by the landfill liner system effectively. Highly chlorinated phenolic compounds in groundwater can be found in higher concentrations than the leachate, as a result of the degradation and transformation of these compounds. Thus, the analysis of highly chlorinated phenolic compounds such as 2,4,6-TCP, 2,3,6-TCP, 3,4,5-TCP, and PCP is of great significance for the studies to be conducted on the contamination of groundwater around landfills.
\end{abstract}

\section{Introduction}

In recent years, the characteristics of wastes in MSW landfills have varied according to the changing habits of consumers. The characteristics of leachate generated from sanitary landfill sites vary according to the waste compounds disposed and the physical, chemical, and biological processes occurring in landfills. Household hazardous wastes such as batteries, paints, oils, electrical products, and pharmaceuticals have a negative impact on environmental and human health [1]. The presence of organic pollutants such as halogenated aliphatic compounds, aromatic hydrocarbons, phenols, and pesticides in leachate indicates that hazardous wastes are also disposed in landfills $[2,3]$.

In studies conducted to determine the pollutants in both leachate and the leachate contaminated groundwater, numerous hazardous substances were identified [4-7]. Phenolic compounds are classified as hazardous substances due to their high toxicity, corrosiveness, flammability, reactivity, and carcinogenic, mutagenic, and ecotoxic properties. Because of these characteristics, phenolic compounds are named as priority pollutants by the US EPA [8]. Since phenolic compounds create unpleasant taste and odor in water even at very low concentrations, the prevention of their migration to groundwater is of great significance. Landfill leachate is one of the major sources of groundwater contamination. Thus, in modern sanitary landfill sites, liner systems are used to prevent the migration of leachate contaminants to groundwater. Liner systems generally consist of a compacted clay liner $(0.3-1.5 \mathrm{~m})$ and a $1-2.5 \mathrm{~mm}$ HDPE (high density polyethylene) geomembrane [9]. The pollutant transfer from landfill leachate to groundwater is generally realized in two ways: geomembrane defects and diffusion [10-13].

Diffusion constitutes the main transport mechanism for the pollutant transport through landfill liners to groundwater [14]. While inorganic pollutants are generally transported through advection or diffusion or by means of their union through geomembrane and liner defects, the transport of volatile organic compounds (VOCs) is realized through diffusion [11, 15-18]. The fate and transport of organic pollutants are affected by processes such as advective, dispersive, and diffusive mass transport through the mineral layer, 


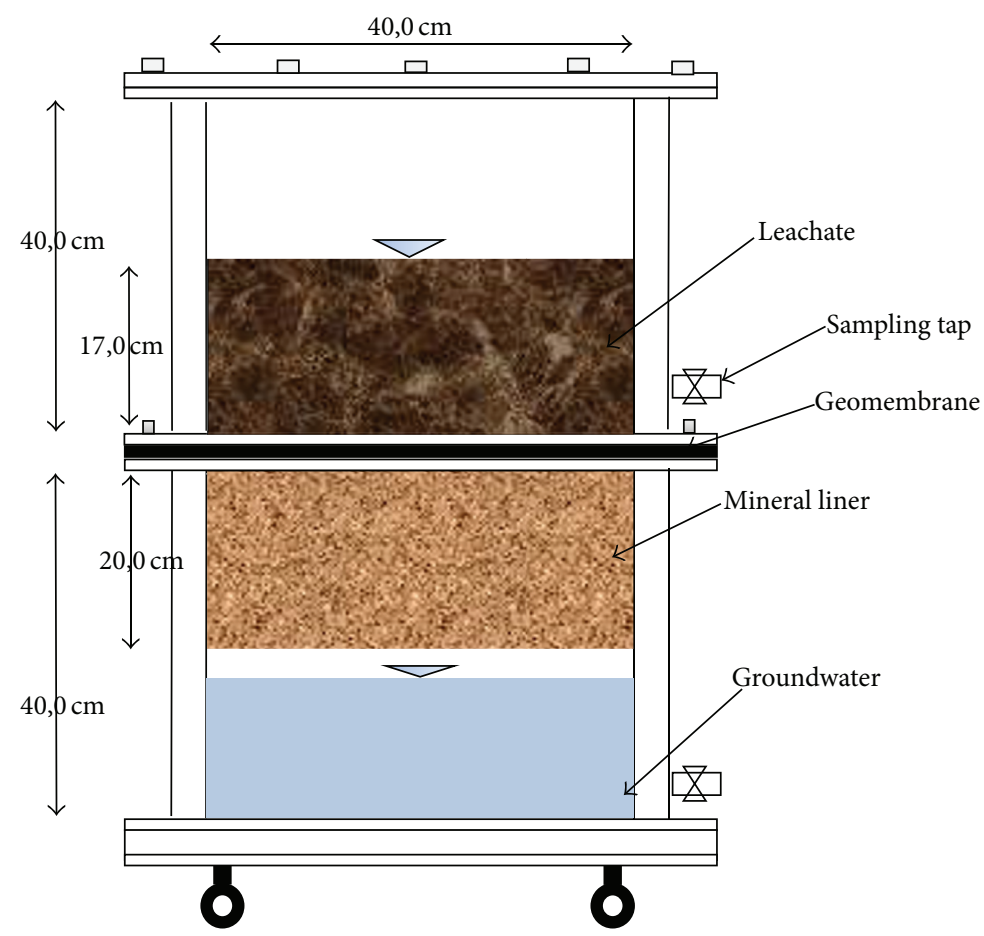

FIgURE 1: Reactors used in the study.

chemical reactions within the soil solution (evaporation, hydrolysis), interaction between the soil solution and the soil pollutants (e.g., adsorption, ion exchange, and precipitation), and biodegradation $[19,20]$. These processes are complex and related with the structure of the waste as well as the material used and the design of the liner system [20].

In recent years, there has been an increase in the number of studies conducted on the effects of leachate on the contamination of water resources $[2,3,21,22]$. The studies have investigated the transport of conventional parameters such as chloride, ammonia, and heavy metals [23-25] and some volatile compounds [9, 13, 26-29] through landfill liners. However, there are only few studies on the transport of phenols and chlorophenols through landfill liners [30, 31]. Phenolic compounds in leachate are generated as a result of the degradation of the phenol-containing compounds in municipal solid waste $[27,32,33]$. Of the four isomers of trichlorophenols investigated in this study (2,4,6-TCP, 2,4,5TCP, 2,3,6-TCP, and 3,4,5-TCP), the 2,4,5- and 2,4,6-isomers are listed on the US EPA's priority pollutants list. The latter has been included in Directive 76/464/EEC (European Economic Community) as a dangerous substance discharged into the aquatic environment $[34,35]$.

The aim of this study was to investigate the performance of different liner materials for the prevention of transport of phenolic compounds to groundwater. Four different liners (clay, bentonite, zeolite, and kaoline) with the same thickness $(20 \mathrm{~cm})$ were used in the simulated reactors. Phenol, 2,4dichlorophenol (2,4-DCP), 2,6-dichlorophenol (2,6-DCP), 2,4,6-trichlorophenol (2,4,6-TCP), 2,4,5-trichlorophenol (2,4,5-TCP), 2,3,6-trichlorophenol (2,3,6-TCP), 3,4,5-trichlo- rophenol (3,4,5-TCP), and pentachlorophenol (PCP) concentrations in leachate and groundwater samples were identified and the performance of different liner materials was determined in order to evaluate the transport of phenolic compounds.

\section{Material and Methods}

2.1. Reactors and Liner Systems. Four lab-scale reactors with a height of $80 \mathrm{~cm}$ and an inner diameter of $40 \mathrm{~cm}$ were used in order to determine the transport of phenolic compounds in landfill leachate through liner systems (Figure 1). The study was conducted at $25^{\circ} \mathrm{C}$. During the study, air was not fed into reactors. The HDPE reactors were comprised of two parts, each with a height of $40 \mathrm{~cm}$.

The upper part of the liner was filled with 20 liters of leachate (app. $17 \mathrm{~cm}$ height) obtained from Odayeri Sanitary Landfill located on the European Side of Istanbul, Turkey. According to the US and the European standards, the maximum leachate load on landfill liner should be $20-50 \mathrm{~cm}$ [36] to improve the performance of the composite liner and to ensure the efficient pump operation. However there is no limit for leachate height in landfill liners in the Landfill Directive used in Turkey. According to this regulation, the hydraulic conductivity of the liner system must be $10^{-9} \mathrm{~m} / \mathrm{s}$ in landfills. The general waste composition and physicochemical characteristics of solid wastes generated in Istanbul were given in our previous study [37].

The liner system of reactors is comprised of $2 \mathrm{~mm}$ thick HDPE geomembrane and $20 \mathrm{~cm}$ thick natural minerals (R1: clay, R2: bentonite, R3: kaoline, and R4: zeolite). The liner 
systems are compacted to prevent the possibilities of leakage at commissioning stage. Mineral layers are filled by the optimum water content obtained from soil analysis. The lower part of the reactors was filled with 25 liters of distilled water representing groundwater.

2.2. Analysis. Leachate characterization was realized before the upper parts of the reactors were filled. $\mathrm{pH}$, electrical conductivity, COD, BOD, TOC, $\mathrm{CI}^{-}$, TKN, $\mathrm{NH}_{3}-\mathrm{N}$, and $\mathrm{SO}_{4}{ }^{-2}$ analysis were conducted according to the standard methods of APHA (2005) [38]. Groundwater samples were collected from reactors to be analyzed biweekly for the first two months and monthly in the following period. Additionally, leachate samples were collected bimonthly for the analysis of the phenolic compounds in order to determine the change in the concentrations as a result of biological activities.

To determine phenol and chlorinated phenolic compounds in leachate and groundwater samples, solid phase microextraction (SPME) method was used as conducted by Ribeiro et al. [39]. The extraction and analysis conditions are given in our previous study [34]. Phenol and chlorophenol concentrations were determined with a Varian 3900 GC-FID gas chromatograph. All of the experiments were repeated 2 times for all parameters and the results are given as an average of these two measurements.

$\mathrm{pH}$, hydraulic conductivity, soil classification, compaction test [40], cation exchange capacity [41], and TOC$\mathrm{TN}$ analyses were performed for the characterization of the mineral materials. TOC-TN analysis was conducted by using Hach Lange IL 550 TOC-TN model apparatus following the thermal oxidation method at high temperature.

\section{Results and Discussions}

3.1. Leachate Characterization. The mean values of leachate characterization analyses realized on 3 different leachate samples are given in Table 1 . In general, the leachate samples demonstrated the characteristics of a middle-aged landfill leachate [42]. Phenol and 2,4-DCP concentrations were higher in leachate samples. The high phenol concentrations can be explained by the reduction of all phenolic compounds to phenol under anaerobic conditions and the slow degradation of phenol in anaerobic landfills.

In the result of repeated experiments, as the values for conventional parameters were near to each other, determined values for phenolic compounds were not near due to volatile properties of phenolic compounds. The studies conducted to determine the phenolic compounds in the leachate also demonstrated that different derivatives of monochlorophenol and pentachlorophenol were present. In the study conducted by Öman and Junestedt [42], the maximum phenol concentration was found to be $4.1 \mu \mathrm{g} / \mathrm{L}$ while the maximum concentration of chlorophenol compounds was determined to $23 \mu \mathrm{g} / \mathrm{L}$. Jiménez et al. [43] reported that PCP, 2,4,6TCP, 2,3,4,6-TeCP, 2,4-DCP, and 3,4-DCP concentrations in the leachate were $0.01-3000,0.08-1.87,0.08-20.4,0.34-12.8$, and $0.27-14.3 \mu \mathrm{g} / \mathrm{L}$, respectively. Another study conducted by Ozkaya [44] revealed that 2,4-DCP, 2,6-DCP, 2,3,4-TCP,
TABLE 1: Leachate characteristics.

\begin{tabular}{lc}
\hline Parameter & Value \\
\hline $\mathrm{pH}$ & 7.8 \\
Conductivity $(\mathrm{mS} / \mathrm{cm})$ & 33 \\
$\mathrm{COD}(\mathrm{mg} / \mathrm{L})$ & 22000 \\
$\mathrm{BOD}(\mathrm{mg} / \mathrm{L})$ & 13000 \\
$\mathrm{TOC}(\mathrm{mg} / \mathrm{L})$ & 6200 \\
$\mathrm{TKN}(\mathrm{mg} / \mathrm{L})$ & 2700 \\
$\mathrm{TP}(\mathrm{mg} / \mathrm{L})$ & 14 \\
$\mathrm{NH}_{3}(\mathrm{mg} / \mathrm{L})$ & 2500 \\
$\mathrm{Cl}^{-}(\mathrm{mg} / \mathrm{L})$ & 4400 \\
$\mathrm{SO}_{4}{ }^{-2}(\mathrm{mg} / \mathrm{L})$ & 500 \\
$\left.\mathrm{Phenol}^{(} \mu \mathrm{g} / \mathrm{L}\right)$ & 26 \\
2,4-Dichlorophenol $(\mu \mathrm{g} / \mathrm{L})$ & 46 \\
2,6-Dichlorophenol $(\mu \mathrm{g} / \mathrm{L})$ & 2.4 \\
2,4,6-Trichlorophenol $(\mu \mathrm{g} / \mathrm{L})$ & 9.5 \\
2,4,5-Trichlorophenol $(\mu \mathrm{g} / \mathrm{L})$ & 8.7 \\
2,3,6-Trichlorophenol $(\mu \mathrm{g} / \mathrm{L})$ & 2.7 \\
3,4,5-Trichlorophenol $(\mu \mathrm{g} / \mathrm{L})$ & $\mathrm{ND}$ \\
Pentachlorophenol $(\mu \mathrm{g} / \mathrm{L})$ & 0.8 \\
\hline
\end{tabular}

2,3,4,5-TeCP, and 2,3,4,6-TeCP were found in acidogenic leachate while only 2,4-DCP was found in methanogenic leachate.

3.2. Soil Characterization. The results of the characterization experiments of clay, bentonite, kaoline, and zeolite used as landfill liner materials in this study are given in Table 2. According to Akyildiz [45], the high pH levels of the four minerals used in the study are the characteristic of compacted soils. Soils are best compacted at their optimum water content, which results in the lowest hydraulic conductivity. According to the results of the compaction and the falling head permeability tests, bentonite was determined to be the mineral with the lowest hydraulic conductivity because of its high water-holding capacity. Furthermore, permeability increases as the size of the particles in the mineral layer increases depending on the silt content. The cation exchange capacity of bentonite is higher than that for the other minerals employed in the study. Accordingly, bentonite is observed to have a higher adsorption capacity.

3.3. Phenolic Compounds in Groundwater and Leachate Samples. The gradual changes of phenolic compounds in leachate and groundwater samples taken from R1, R2, R3, and $\mathrm{R} 4$ reactors are given in Figures 2-5, respectively. The demonstrated results are the average of two measurements for each sample.

The average phenol concentrations in leachate samples of $\mathrm{R} 1, \mathrm{R} 2, \mathrm{R} 3$, and R4 reactors were 6.91, 6.91, 6.67, and $6.77 \mu \mathrm{g} / \mathrm{L}$, respectively. The observed phenol concentrations decreased in all of the reactors during the study because of the decomposition of phenolic compounds. Results indicated that phenol concentrations decreased rapidly during the first two months of operation and that phenol degradation 
TABLE 2: Properties of the mineral materials used in the study.

\begin{tabular}{lccccccc}
\hline Material & $\mathrm{pH}$ & $\begin{array}{c}\text { Clay } \\
\text { content (\%) }\end{array}$ & $\begin{array}{c}\text { Silt content } \\
(\%)\end{array}$ & Soil classification & $\begin{array}{c}\text { Hydraulic } \\
\text { conductivity (m/s) }\end{array}$ & $\begin{array}{c}\text { Optimum water } \\
\text { content }(\%)\end{array}$ & $\begin{array}{c}\text { CEC } \\
(\mathrm{meq} / 100 \mathrm{~g})\end{array}$ \\
\hline Clay (R1) & 7.4 & 85 & 15 & CH-inorganic clays of high plasticity & $6.3 \times 10^{-8}$ & 27 & 19.3 \\
Bentonite (R2) & 8.8 & 89 & 11 & CH-inorganic clays of high plasticity & $2.7 \times 10^{-10}$ & 41 & 48.6 \\
Kaoline (R3) & 7.7 & 57 & 43 & ML-inorganic silts with slight plasticity & $3.1 \times 10^{-7}$ & 23.5 & 10.1 \\
Zeolite (R4) & 8.1 & 19 & 81 & MH-inorganic silts with high plasticity & $8.8 \times 10^{-8}$ & 40 & 20.2 \\
\hline
\end{tabular}

occurs faster than that for the other phenolic compounds investigated in anaerobic medium. Phenol concentrations in groundwater samples taken from all reactors were around $0.2 \mu \mathrm{g} / \mathrm{L}$ on average. The average migration rates of phenol from leachate to groundwater were accordingly determined to be below $2 \%$ for all reactors. Thus, it can be concluded that the change of mineral materials used in landfill liner systems will not have an effect on phenol transport to groundwater. The results also indicated that the decrease in phenol concentrations is not derived from the migration while anaerobic biodegradation and sorption may be responsible for the reduction of phenol concentrations.

The average 2,4-DCP concentrations in leachate samples during 180 days of operation were determined as 11.7, 11.6, 15.5, and $19.4 \mu \mathrm{g} / \mathrm{L}$ for R1, R2, R3, and R4 reactors, respectively. The reduction in 2,4-DCP concentrations in leachate shows the same trend that was observed for the phenol concentrations, and the leachate concentrations decreased rapidly in the first two months of operation. The results of the groundwater analysis for 2,4-DCP resulted in average concentrations of $0.38,0.26,0.55$, and $0.24 \mu \mathrm{g} / \mathrm{L}$ for $\mathrm{R} 1, \mathrm{R} 2, \mathrm{R} 3$, and $\mathrm{R} 4$ reactors, indicating $3.2,2.3,3.6$, and $1.2 \%$ of migration, respectively. The results show that zeolite (R4) and bentonite (R2) are effective materials and kaoline (R3) is the least effective liner for the prevention of 2,4-DCP transport to groundwater. It can also be concluded that sorption and biodegradation are effectively removing 2,4-DCP from leachate.

A similar trend can be seen for 2,6-DCP in leachate samples, but the decrease was not observed as fast as 2,4-DCP. The observed leachate concentrations were $3.25 \mu \mathrm{g} / \mathrm{L}$ for R1 and $\mathrm{R} 2$ reactors and 3.98 and $4.12 \mu \mathrm{g} / \mathrm{L}$ for $\mathrm{R} 3$ and $\mathrm{R} 4$ reactors, respectively. The average groundwater concentrations were also very close to each other (app. $0.4 \mu \mathrm{g} / \mathrm{L}$ ) except for the kaoline (R3) reactor which had the highest 2,6-DCP concentration $(0.68 \mu \mathrm{g} / \mathrm{L})$. Based on the experimental results, transport percentage of 2,6-DCP from landfill leachate to groundwater was determined to be about $12.3 \%, 12.7 \%, 17.1 \%$, and $8.7 \%$ for R1, R2, R3, and R4 reactors, respectively. Results indicated that zeolite is the most effective and kaoline is the least effective liner material for the transport of 2,6-DCP to groundwater from landfills.

Average concentrations of 2,4,6-TCP were determined as $2.92,3.45,2.78$, and $2.73 \mu \mathrm{g} / \mathrm{L}$ in leachate samples and 18.27, $22.83,14.47$, and $17.63 \mu \mathrm{g} / \mathrm{L}$ in groundwater samples for R1, $\mathrm{R} 2, \mathrm{R} 3$, and R4 reactors, respectively. The concentrations in the groundwater samples are almost six times higher than that of the leachate concentrations [46]. The same trend was observed for the other trichlorophenol isomers except for
2,4,5-TCP. As a result of reductive dehalogenation processes, multichlorophenols are usually transformed to mono- or dichlorophenols under anaerobic conditions [47]. According to Yang et al. [48] the dechlorination rate of chlorophenols decreases with increasing number of chlorine substituents on the aromatic ring. Although anaerobic dechlorination of more highly chlorinated chlorophenols follows by anaerobic mineralization of the resulting monochlorophenols, these compounds are both prone to leaching into the water and persistent in soils [49]. Also, chlorophenols can easily migrate in groundwater because of their solubility in water [50]. It has been reported that bioaccumulation potential correlated to the octanol water partition coefficient (Kow) followed the order of 2 - $\mathrm{CP}<4$ - $\mathrm{CP}<2,4,5-\mathrm{TCP}<2,4,6-\mathrm{TCP}<2,3,4,6-\mathrm{TeCP}<$ PCP [49]. Therefore, it is seen that trichlorophenols $(2,4,6-$ TCP, 2,3,6-TCP, 3,4,5-TCP, and 2,4,5-TCP) had a higher potential of migration to groundwater in all reactors. Results indicated that all of the mineral liners are not effective in preventing the trichlorophenol migration from landfills.

The average PCP concentrations for R1, R2, R3, and R4 reactors were determined as $2.26,0.94,0.83$, and $0.64 \mu \mathrm{g} / \mathrm{L}$ in leachate samples and 1.60, 1.58, 1.26, and $1.04 \mu \mathrm{g} / \mathrm{L}$ in groundwater samples, respectively. PCP concentrations increased in the groundwater samples except for $\mathrm{R} 1$ reactor. The results indicated that PCP transport to groundwater could not be prevented by using different mineral layers from landfill liners. Previous studies have demonstrated that the removal of PCP by aerobic bacteria was not possible; however, dechlorination under anaerobic conditions would be efficient. Under anaerobic conditions, PCP is first reduced to TeCP compounds, then to TCP and DCP compounds, respectively, and finally to phenol to be mineralized [51]. In the first 100 days of operation, PCP concentrations of the groundwater samples taken from the reactors were determined to be at high levels which indicates that the mineralization process of PCP was very slow. As a general result, the concentrations of highly chlorinated phenolic compounds in groundwater samples are higher than that of the leachate samples due to the degradation and transformation of phenolic compounds. Highly chlorinated phenolic compounds demonstrated slower transformation compared to other phenolic compounds resulting in an easier migration of these compounds into the groundwater than that for the other chlorinated compounds of this study.

The dominant mechanism for the transport of phenol and phenolic compounds from leachate to groundwater is molecular diffusion. Geomembranes are ineffective in organic contaminant transport [30]. The findings indicated 

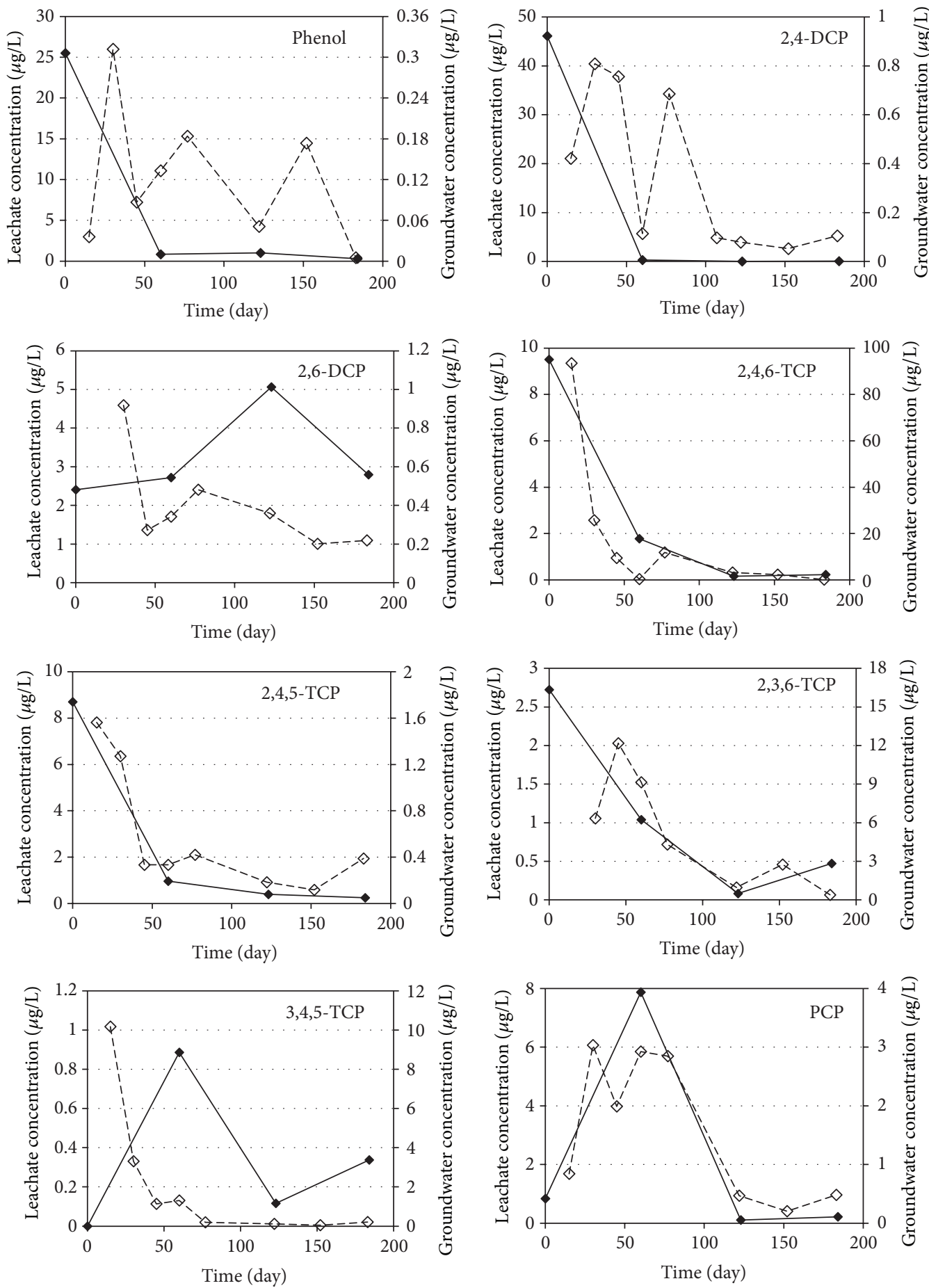

FIGURE 2: Variations of the phenolic compounds in groundwater and leachate samples of R1 reactor (— - leachate concentration, - - - - : groundwater concentration).

that only mono- and dichlorophenols migration can be prevented by mineral layers, but these layers are ineffective in delaying the transport of polychlorinated phenolic compounds. Additionally, the four mineral layers used in this study failed to prevent the transport of contaminants but that the migration of phenolic compounds to groundwater can be decreased by the use of zeolite material in landfill liners.
Adsorption can also be considered as a fundamental affecting the migration of phenolic compounds to groundwater by landfill liners. Chaouati et al. [52] showed that adsorption of phenol onto zeolites $\mathrm{Y}$ modified by silylation that are one of synthetic zeolites was very fast and supported at acidic conditions. Synthetic zeolites have different pore size and $\mathrm{Si} / \mathrm{Al}$ ratio affecting the adsorption rates. Also they 

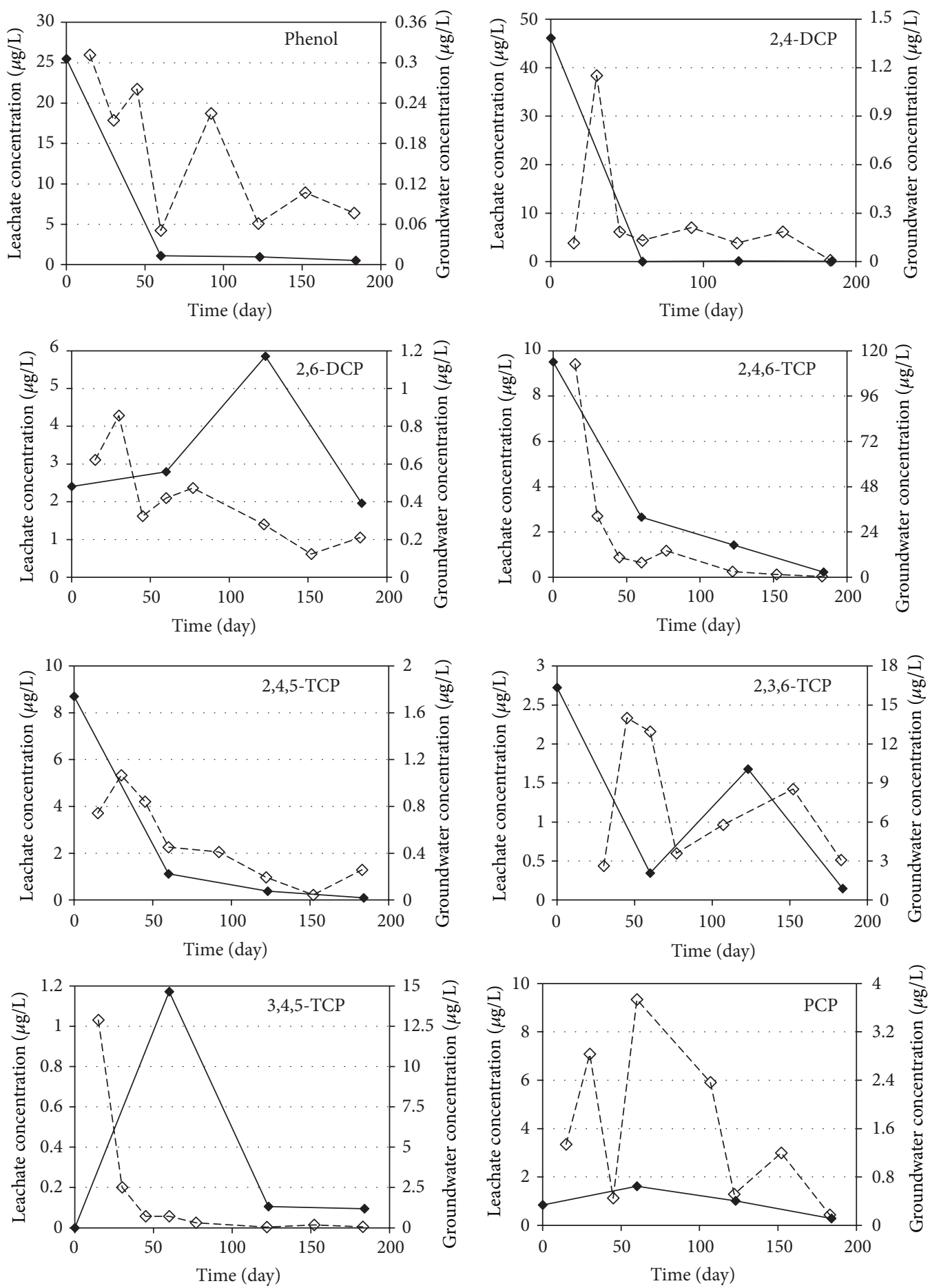

FIGURE 3: Variations of the phenolic compounds in groundwater and leachate samples of R2 reactor (— groundwater concentration).

found that phenol adsorption increases with $\mathrm{Si} / \mathrm{Al}$ ratio. Damjanović et al. [53] also reported that hydrophobic zeolites that possess higher contents of Si show higher affinities for phenol adsorption. In the present study, zeolite has the highest $\mathrm{Si} / \mathrm{Al}$ ratio indicating the higher affinity for phenol adsorption.

\section{Conclusion}

Four lab-scale HDPE reactors with different liner materials (clay, bentonite, kaoline, and zeolite) were used in order to determine the transport of phenolic compounds in landfill leachate through liner systems. Leachate samples used in 

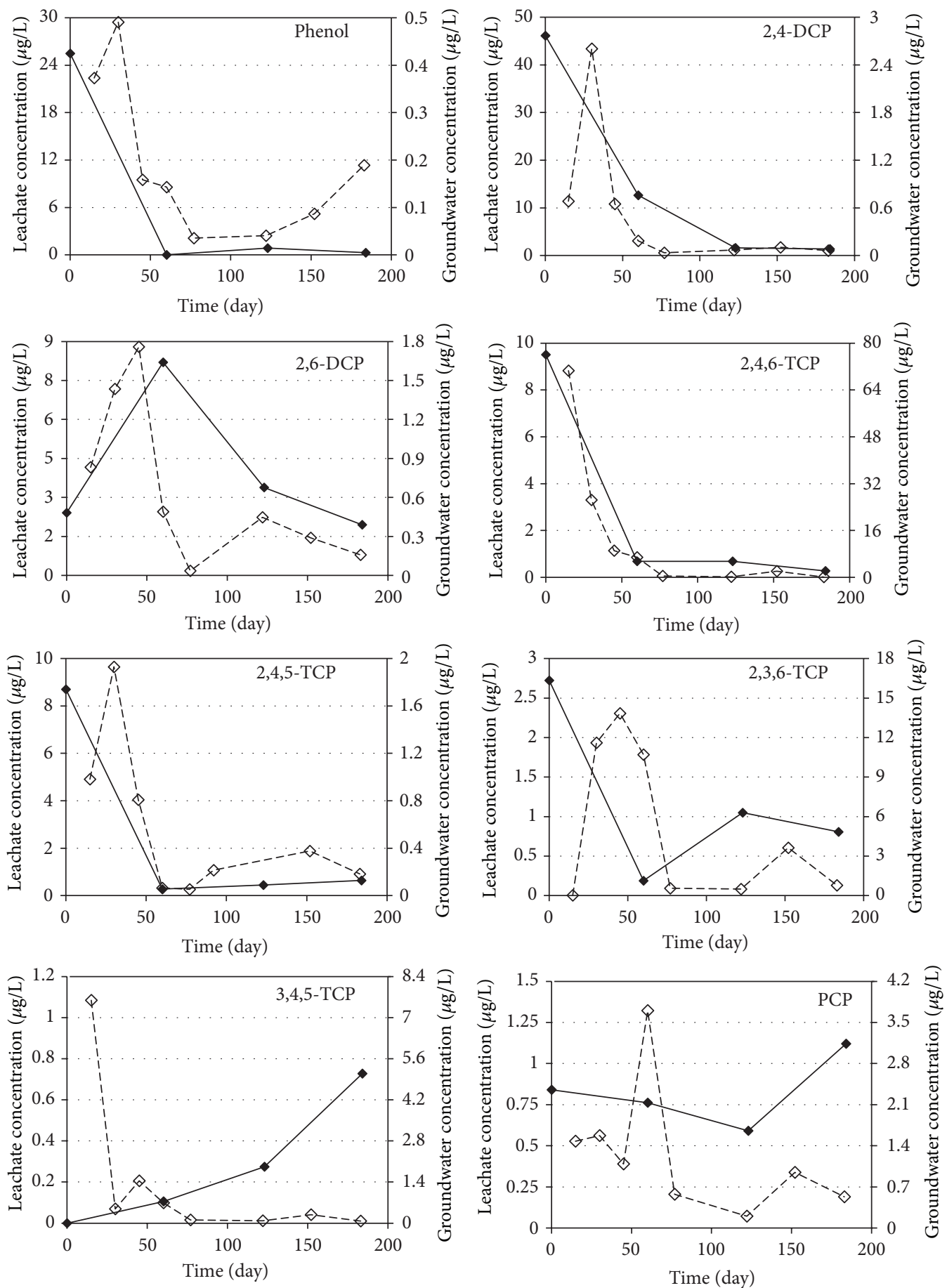

FIGURE 4: Variations of the phenolic compounds in groundwater and leachate samples of R3 reactor (— — leachate concentration, - - - - -: groundwater concentration).

the study correspond to a middle-aged landfill leachate. The reduction of all phenolic compounds to phenol as an end product caused the high concentrations of phenol in raw leachate. According to the soil analysis, bentonite seems to have the lowest hydraulic conductivity and a higher adsorption capacity.
Experimental results indicated that the mineral materials used in landfill liners will not have an effect on monoand dichlorophenol transport to groundwater. The observed decrease of these compounds in leachate samples was derived from biodegradation and sorption mechanisms. The reason for the high concentrations of highly chlorinated phenolic 

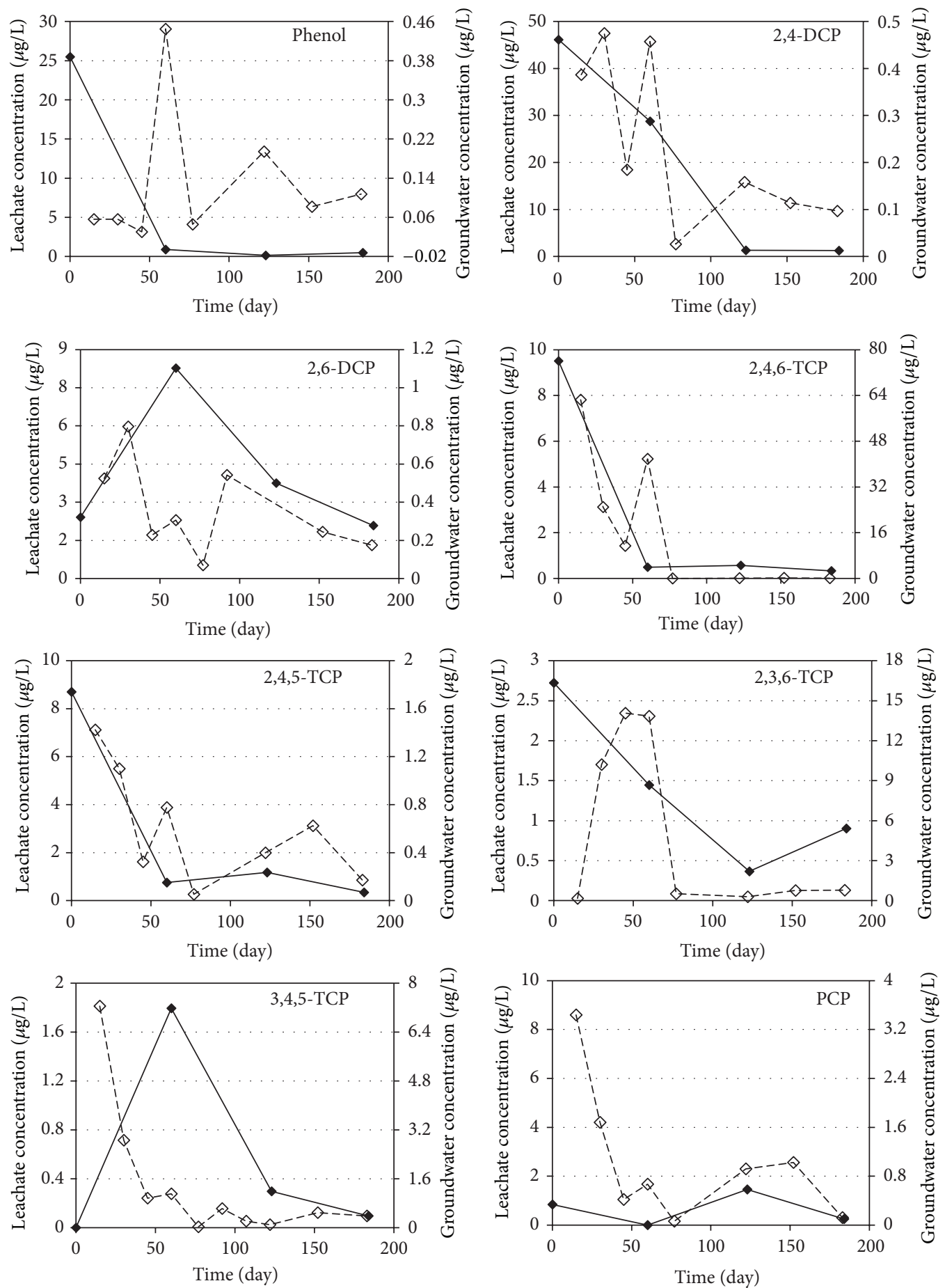

FiguRE 5: Variations of the phenolic compounds in groundwater and leachate samples of R4 reactor (— : leachate concentration, - - - --: groundwater concentration).

compounds in groundwater samples can be explained by the transformation of phenolic compounds under anaerobic conditions. Highly chlorinated phenolic compounds demonstrated slower degradation compared to other phenolic compounds resulting in a substantial migration of these compounds to groundwater.

As a general result, mono- and dichlorophenols migration can be prevented by mineral layers, but these layers are ineffective for polychlorinated phenolic compounds. Additionally, the four mineral layers used in this study failed to prevent the transport of contaminants. However, the migration of phenolic compounds to groundwater can be decreased with the use of zeolite material in landfill liners. It was also determined that the transport of highly chlorinated phenolic compounds from mineral layer is possible through different processes. Due to degradation and transformation 
activities, these compounds can be found in groundwater with higher concentrations than the leachate. Therefore, the analysis of highly chlorinated compounds such as 2,4,6-TCP, 2,3,6-TCP, 3,4,5-TCP, and PCP is of great significance for the studies to be conducted on the contamination of groundwater around landfills by leachate.

As a result of this work, the best of four different materials used may be zeolite because of high silt content and adsorption capacity. Adsorption studies by using zeolite and/or zeolite + clay mixture can be conducted to determine the best material minimizing the migration of leachate contaminants to groundwater for the future studies.

\section{Conflict of Interests}

The authors declare that there is no conflict of interests regarding the publication of this paper.

\section{Acknowledgments}

This research has been supported by the Scientific Research Projects Coordinatorship of Yildiz Technical University (BAP) (Project no. 2011-05-02-KAP01), Istanbul, Turkey. The authors wish to acknowledge ISTAC (Istanbul Metropolitan Municipality Environment Protection and Waste Material Recycling Inc.) for their support during the study.

\section{References}

[1] T. Eggen, M. Moeder, and A. Arukwe, "Municipal landfill leachates: a significant source for new and emerging pollutants," Science of the Total Environment, vol. 408, no. 21, pp. 5147-5157, 2010.

[2] T. H. Christensen, P. Kjeldsen, P. L. Bjerg et al., "Review: biogeochemistry of landfill leachate plume," Applied Geochemistry, vol. 16, pp. 659-718, 2001.

[3] P. Kjeldsen, M. A. Barlaz, A. P. Rooker, A. Baun, A. Ledin, and T. H. Christensen, "Present and long-term composition of MSW landfill leachate: a review," Critical Reviews in Environmental Science and Technology, vol. 32, no. 4, pp. 297-336, 2002.

[4] C. Oman and P.-A. Hynning, "Identification of organic compounds in municipal landfill leachates," Environmental Pollution, vol. 80, no. 3, pp. 265-271, 1993.

[5] United States Environmental Protection Agency (USEPA), "Evaluation and characterization of landfill leachates," Draft Report, Science Applications International Corporation, Reston, Va, USA, 2000.

[6] R. K. Rowe and C. B. Lake, "Volatile organic compound diffusion and sorption coefficients for a needle-punched GCL," Geosynthetics International, vol. 11, no. 4, pp. 257-272, 2004.

[7] H. Xie, Y. Chen, H. Ke, X. Tang, and R. Chen, "Analysis of diffusion-adsorption equivalency of landfill liner systems for organic contaminants," Journal of Environmental Sciences, vol. 21, no. 4, pp. 552-560, 2009.

[8] N. Calace, E. Nardi, B. M. Petronio, and M. Pietroletti, "Adsorption of phenols by papermill sludges," Environmental Pollution, vol. 118, no. 3, pp. 315-319, 2002.

[9] T. B. Edil, "A review of aqueous-phase VOC transport in modern landfill liners," Waste Management, vol. 23, no. 7, pp. 561-571, 2003.
[10] G. J. Foose, Leakage rates and chemical transport through composite liners [Ph.D. dissertation], Department of Civil and Environmental Engineering, University of Wisconsin-Madison, Madison, Wis, USA, 1997.

[11] T. Katsumi, C. H. Benson, G. J. Foose, and M. Kamon, "Performance-based design of landfill liners," Engineering Geology, vol. 60 , no. 1-4, pp. 139-148, 2001.

[12] G. J. Foose, C. H. Benson, and T. B. Edil, "Analytical equations for predicting concentration and mass flux from composite liners," Geosynthetics International, vol. 8, no. 6, pp. 551-575, 2001.

[13] G. J. Foose, C. H. Benson, and T. B. Edil, "Comparison of solute transport in three composite liners," Journal of Geotechnical and Geoenvironmental Engineering, vol. 128, no. 5, pp. 391-403, 2002.

[14] Y.-S. Jang and G.-T. Hong, "Analysis of effective diffusion and transport of inorganic solute through a landfill liner system," Environmental Geology, vol. 42, no. 8, pp. 929-936, 2002.

[15] W. Mueller, R. Jakob, R. Tatzky-Gerth, and H. August, "Solubilities, diffusion and partition coefficients of organic pollutants in HDPE geomembranes: experimental results and calculations," in Proceedings of the 6th International Conference on Geosynthetics, Atlanta, Ga, USA, 1998.

[16] J. K. Park and M. Nibras, "Mass flux of organic chemicals through polyethylene geomembranes," Water Environment Research, vol. 65, no. 3, pp. 227-237, 1993.

[17] H. P. Sangam and R. K. Rowe, "Migration of dilute aqueous organic pollutants through HDPE geomembrane," Geotextiles and Geomembranes, vol. 19, no. 6, pp. 329-357, 2001.

[18] G. J. Foose, "A steady-state approach for evaluating the impact of solute transport through composite liners on groundwater quality," Waste Management, vol. 30, no. 8-9, pp. 1577-1586, 2010.

[19] G. Wu and L. Y. Li, "Modeling of heavy metal migration in sand/bentonite and the leachate $\mathrm{pH}$ effect," Journal of Contaminant Hydrology, vol. 33, no. 3-4, pp. 313-336, 1998.

[20] J. M. Saquing, D. R. U. Knappe, and M. A. Barlaz, "Fate and transport of phenol in a packed bed reactor containing simulated solid waste," Waste Management, vol. 32, no. 2, pp. 327-334, 2012.

[21] Y. Abu-Rukah and O. Al-Kofahi, "The assessment of the effect of landfill leachate on ground-water quality - a case study. ElAkader landfill site-North Jordan," Journal of Arid Environments, vol. 49, no. 3, pp. 615-630, 2001.

[22] J. Saarela, "Pilot investigations of surface parts of three closed landfills and factors affecting them," Environmental Monitoring and Assessment, vol. 84, no. 1-2, pp. 183-192, 2003.

[23] S. F. Thorton, D. N. Lerner, and J. H. Tellam, "Attenuation of landfill leachate by clay liner materials in laboratory columns: 2 . Behaviour of inorganic contaminants," Waste Management and Research, vol. 19, no. 1, pp. 70-88, 2001.

[24] A. A. Roberts and T. Shimaoka, "Analytical study on the suitability of using bentonite coated gravel as a landfill liner material," Waste Management, vol. 28, no. 12, pp. 2635-2644, 2008.

[25] J. Cuevas, S. Leguey, A. Garralón et al., "Behavior of kaolinite and illite-based clays as landfill barriers," Applied Clay Science, vol. 42, no. 3-4, pp. 497-509, 2009.

[26] U. Kalbe, W. W. Müller, W. Berger, and J. Eckardt, "Transport of organic contaminants within composite liner systems," Applied Clay Science, vol. 21, no. 1-2, pp. 67-76, 2002. 
[27] A. Baun, L. A. Reitzel, A. Ledin, T. H. Christensen, and P. L. Bjerg, "Natural attenuation of xenobiotic organic compounds in a landfill leachate plume (Vejen, Denmark)," Journal of Contaminant Hydrology, vol. 65, no. 3-4, pp. 269-291, 2003.

[28] T. Itakura, D. W. Airey, and C. J. Leo, "The diffusion and sorption of volatile organic compounds through kaolinitic clayey soils," Journal of Contaminant Hydrology, vol. 65, no. 3-4, pp. 219-243, 2003.

[29] H. J. Lu, M. T. Luan, and J. L. Zhang, "Study on transport of Cr(IV) through the landfill liner composed of two layer soils," Desalination, vol. 266, no. 1-3, pp. 87-92, 2011.

[30] G. Varank, A. Demir, K. Yetilmezsoy, M. S. Bilgili, S. Top, and E. Sekman, "Estimation of transport parameters of phenolic compounds and inorganic contaminants through composite landfill liners using one-dimensional mass transport model," Waste Management, vol. 31, no. 11, pp. 2263-2274, 2011.

[31] M. J. A. Mendes, N. Touze-Foltz, M. Gardoni, M. Ahari, and L. Mazeas, "Quantification of diffusion of phenolic compounds in virgin GCL and in GCL after contact with a synthetic leachate," Geotextiles and Geomembranes, vol. 38, pp. 16-25, 2013.

[32] A. Karlsson, J. Ejlertsson, D. Nezirevic, and B. H. Svensson, "Degradation of phenol under meso- and thermophilic, anaerobic conditions," Anaerobe, vol. 5, no. 1, pp. 25-35, 1999.

[33] A. L. Reitzel and A. Ledin, "Determination of phenols in landfill leachate-contaminated groundwaters by solid-phase extraction," Journal of Chromatography, vol. 972, no. 2, pp. 175-182, 2002.

[34] R. Yazici, E. Sekman, S. Top, G. Varank, and M. S. Bilgili, "Degradation of phenolic compounds in aerobic and anaerobic landfills: a pilot scale study," Waste Management \& Research, vol. 30, no. 5, pp. 542-550, 2012.

[35] L. Kharoune, M. Kharoune, and J. M. Lebeault, "Aerobic biodegradation of 2,4,6-trichlorophenol by a microbial consortium-selection and characterization of microbial consortium," Applied Microbiology and Biotechnology, vol. 59, no. 1, pp. 112$117,2002$.

[36] 2015, http://www.geosynthetica.net/Uploads/GSI_WhitePaper 26.pdf.

[37] M. S. Bilgili, "Adsorption of 4-chlorophenol from aqueous solutions by xad- 4 resin: isotherm, kinetic, and thermodynamic analysis," Journal of Hazardous Materials, vol. 137, no. 1, pp. 157164, 2006.

[38] American Public Health Association, Standard Methods for the Examination of Water and Wastewater, APHA, Washington, DC, USA, 20th edition, 2005.

[39] A. Ribeiro, M. H. Neves, M. F. Almeida, A. Alves, and L. Santos, "Direct determination of chlorophenols in landfill leachates by solid-phase micro-extraction-gas chromatography-mass spectrometry," Journal of Chromatography A, vol. 975, no. 2, pp. 267274, 2002.

[40] ASTM, Annual Book of ASTM Standards, ASTM, 1991.

[41] K. G. Bhattacharyya and S. S. Gupta, "Kaolinite, montmorillonite, and their modified derivatives as adsorbents for removal of $\mathrm{Cu}(\mathrm{II})$ from aqueous solution," Separation and Purification Technology, vol. 50, no. 3, pp. 388-397, 2006.

[42] C. B. Öman and C. Junestedt, "Chemical characterization of landfill leachates-400 parameters and compounds," Waste Management, vol. 28, no. 10, pp. 1876-1891, 2008.

[43] L. Jiménez, R. Alzaga, and J. M. Bayona, "Determination of organic contaminants in landfill leachates: a review," International Journal of Environmental Analytical Chemistry, vol. 82, no. 7, pp. 415-430, 2002.
[44] B. Ozkaya, "Chlorophenols in leachates originating from different landfills and aerobic composting plants," Journal of Hazardous Materials, vol. 124, no. 1-3, pp. 107-112, 2005.

[45] M. H. Akyildiz, Investigation of parameters effecting impermeability in regular solid waste disposal sites [Ph.D. thesis], Institute of Science, Sakarya University, Sakarya, Turkey, 2011.

[46] E. Adar, Investigation of migration of leachate contaminants through alternative landfill liner systems [M.S. thesis], Environmental Engineering, Institute of Science, Yildız Technical University, Istanbul, Turkey, 2013.

[47] H. Gardin, J. M. Lebeault, and A. Pauss, "Degradation of 2,4,6trichlorophenol $(2,4,6-\mathrm{TCP})$ by co-immobilization of anaerobic and aerobic microbial communities in an upflow reactor under air-limited conditions," Applied Microbiology and Biotechnology, vol. 56, no. 3-4, pp. 524-530, 2001.

[48] S. Yang, A. Shibata, N. Yoshida, and A. Katayama, "Anaerobic mineralization of pentachlorophenol (PCP) by combining PCPdechlorinating and phenol-degrading cultures," Biotechnology and Bioengineering, vol. 102, no. 1, pp. 81-90, 2009.

[49] A. P. Annachhatre and S. H. Gheewala, "Biodegradation of chlorinated phenolic compounds," Biotechnology Advances, vol. 14, no. 1, pp. 35-56, 1996.

[50] P. M. Armenante, D. Kafkewitz, G. A. Lewandowski, and C.J. Jou, "Anaerobic-aerobic treatment of halogenated phenolic compounds," Water Research, vol. 33, no. 3, pp. 681-692, 1999.

[51] S.-T. Chen, C.-Y. Hsu, and P. M. Berthouex, "Fate and modeling of pentachlorophenol degradation in a laboratory-scale anaerobic sludge digester," Journal of Environmental Engineering, vol. 132, no. 7, pp. 795-802, 2006.

[52] N. Chaouati, A. Soualah, and M. Chater, "Adsorption of phenol from aqueous solution onto zeolites Y modified by silylation," Comptes Rendus Chimie, vol. 16, no. 3, pp. 222-228, 2013.

[53] L. Damjanović, V. Rakić, V. Rac, D. Stošić, and A. Auroux, "The investigation of phenol removal from aqeous solutions by zeolites as solid adsorbents," Journal of Hazardous Materials, vol. 184, no. 1-3, pp. 477-484, 2010. 

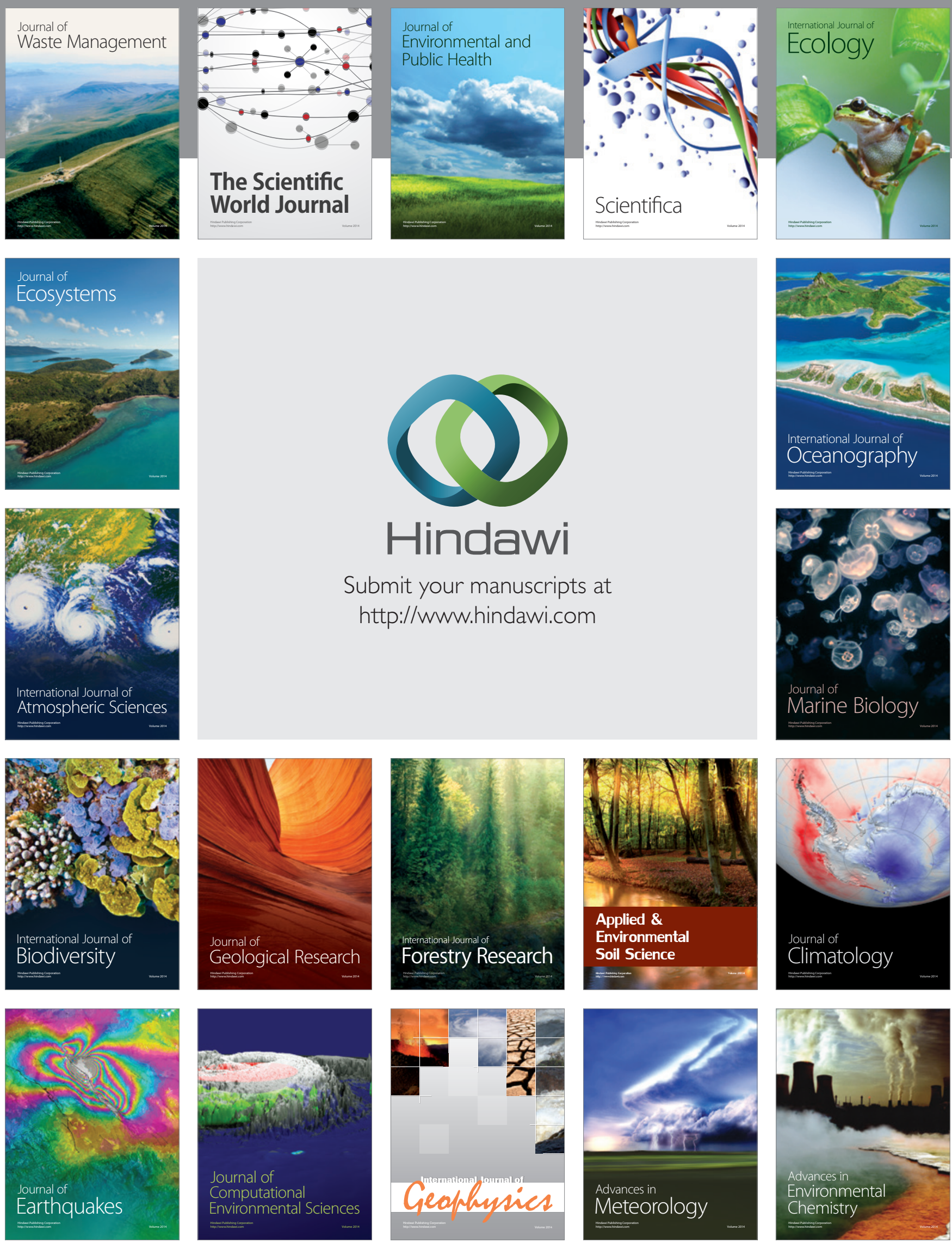